\title{
ANALISIS SEISMOGRAM TIGA KOMPONEN TERHADAP MOMENT TENSOR GEMPA BUMI DI MANOKWARI PAPUA 03 JANUARI 2009
}

\author{
Irwan Setyowidodo ${ }^{1}$, Bagus Jaya Santosa ${ }^{2}$
}

\begin{abstract}
Abstrak: Penelitian ini melakukan analisis inversi waveform 3 komponen terhadap data gempa bumi yang terjadi di Manokwari Papua pada tanggal 3 Januari 2009 pukul 19:43:55 GMT dengan magnitude 7.1 Mw yang episentrumnya berada pada lattitude -0.70541 , longitude 125.8455 dan kedalaman $25 \mathrm{~km}$. Data yang digunakan dalam penelitian ialah, data seismik lokal yang diunduh dari data gempa IA. Selanjutnya dilakukan proses inversi data waveform tiga komponen dengan menggunakan metode iterasi dekonvolusi. Metode ini diimplementasikan dalam software ISOLA yang dikembangkan untuk mendapatkan parameter-parameter sumber gempa bumi. Parameterparameter gempa ini tergambarkan dalam Centroid Moment Tensor dan parameter sesar penyebab gempa. Selanjutnya, hasil parameter-patameter tersebut digunakan untuk mengetahui arah patahan yang sebenarnya (fault-plane) dengan menggunakan metode $\mathrm{H}-\mathrm{C}$.

Seismogram sintetik dihitung dengan ISOLA yang inputnya adalah model bumi dan data seismogram yang direkam oleh stasiun seismologi BAK, LBM dan JAY. Hasil interpretasi atas analisis seismogram waveform tiga komponen menunjukkan bahwa orientasi bidang patahan gempa Manokwari Papua pada tanggal 3 Januari 2009 memiliki sudut dip 54 ${ }^{\circ}$ terhadap bidang horizontal yang menyebabkan zona patahan di daerah tersebut mudah bergeser dan mudah terjadi gempa. Hasil analisis ini diketahui bahwa sesar penyebab gempa bumi ini ialah sesar strike-slip oblique yang bergerak dari arah barat laut - tenggara. Sumber gempa bumi yang terjadi tersebut terjadi akibat aktivitas Sesar Sorong yang terdapat di bagian utara Manokwari.
\end{abstract}

Kata kunci: inversi waveform, sesar, centroid moment tensor, Papua

\section{PENDAHULUAN}

Secara geografis, kepulauan Indonesia berada di antara $6^{0} \mathrm{LU}$ dan $11^{0} \mathrm{LS}$ serta $95^{\circ} \mathrm{BT}-141^{0} \mathrm{BT}$, selain itu juga terletak pada perbenturan tiga lempeng kerak bumi yaitu lempeng Eurasia, lempeng Pasifik, dan lempeng India Australia. Ditinjau secara geologis, kepulauan Indonesia berada pada pertemuan 2 jalur gempa utama, yaitu jalur gempa Sirkum Pasifik dan jalur gempa Alpide Transasiatic. Karena itu, kepulauan Indonesia berada pada daerah yang mempunyai aktivitas gempa bumi cukup tinggi.

Pergerakan lempeng-lempeng raksasa menimbulkan gesekan-gesekan, tekanan dan desakan pada bidang pertemuanya. Tekanan yang timbul akibat pergerakan lempeng-lempeng tersebut terus membesar. Maka, pada suatu saat ketika tidak dapat menahan tekanan besar tersebut, batuan menjadi pecah dan terangkat. Pelepasan tekanan ini menimbulkan getaran atau gelombang. Gelombang kemudian menyebar ke segala penjuru dari titik dimana batuan pecah atau terangkat dan menghasilkan guncangan/getaran pada bumi yang disebut gempa bumi. Banyak studi telah dikembangkan untuk memahami struktur dan dinamika dalam bumi serta mekanisme gempa bumi melalui estimasi parameter sumber gempa Centroid Moment Tensor

1 and 2 Prodi Geofisika, Jurusan Fisika, FMIPA, Institut Teknologi Sepuluh Nopember, Surabaya 60111, Indonesia (E-mail: setyowidodo09@.mhs.physics.its.ac.id) 
$(C M T)$. Penentuan CMT gempa bumi selama ini menggunakan fungsi Green satu komponen yakni pada arah sumbu $\mathrm{Z}$ saja. Gelombang seismik merambat dari sumber menuju stasiun observasi dalam ruang tiga dimensi, oleh karena itu dikembangkanlah fungsi Green 3 komponen untuk mengestimasi parameter sumber gempa tersebut secara cermat.Penelitian ini membandingan waveform terukur oleh stasiun dan waveform sintetik yang telah terhitung melalui fungsi Green berbasis waveform tiga komponen dalam seismogram.

Pemahaman terhadap karakteristik sesar yang mengakibatkan gempa bumi juga diperlukan untuk memperkirakan atau mengetahui karakter dan akibat kegempaan. Untuk memahami karakteristik ini dapat dilakukan dengan memodelkan moment tensor gempa bumi (Shearer, 2009). Pemodelan moment tensor ini didapat dilakukan dengan menggunakan metode inversi yang memanfaatkan waveform ataupun waktu tiba gelombang P (Zahradnick, 2008). Analisis data yang digunakan dalam penelitian ialah, data seismik lokal yang diunduh dari data gempa IA. Hasil analisis ini berupa parameter-parameter gempa bumi yang meliputi; skala, kedalaman dan energi gempa bumi serta model patahan penyebab gempa bumi. Pada makalah ini, disajikan hasil analisis waveform 3 komponen terhadap gempa bumi di Manokwari Papua pada tanggal 3 Januari 2009 dengan magnitude 7.1 Mw yang episentrumnya berada pada lattitude 0.70541 , longitude 125.8455 dan kedalaman $25 \mathrm{~km}$.

\section{KAJIAN TEORI}

\section{Moment Tensor}

Gempa bumi disebabkan adanya gerakan suatu sesar dengan karakter gerak tertentu. Model gerak sesar dan karakter sesar penyebab gempa bumi dapat diketahui berdasarkan moment tensor gempa bumi. Moment tensor ini digunakan untuk

menggambarkan arah gaya penyebab gempa bumi. Berdasarkan persamaan dari suku fungsi Green,

$$
u(x)=\int_{-\infty}^{\infty} G\left(x ; x^{\prime}\right) f\left(x^{\prime}\right) d x^{\prime}
$$

maka komponen rekaman seismik dari sebuah titik sumber dapat dinyatakan sebagai berikut:

$$
U_{k}(x, t)=\sum_{i=1}^{6} G_{k i}\left(x, x_{s}, t\right) * f_{i}(t)
$$

Keterangan:

$\mathrm{U}_{\mathrm{k}}=$ rekaman pergeseran pada komponen ke- $k$

$\mathrm{x}=$ posisi reciever

$\mathrm{x}_{\mathrm{s}}=$ posisi sumber gempa

$\mathrm{G}_{\mathrm{ki}}=$ fungsi Green, bergantung sifat elastik dan anelastik dari bumi dan tanda bintang menunjukkan konvolusi.

$f_{i}(t)=$ menyatakan 6 komponen moment tensor dasar independen. 
Dalam koordinat bola, keenam moment tensor tersebut adalah:

$$
\mathrm{f}_{1}=\mathrm{M}_{\mathrm{rr}}, \mathrm{f}_{2}=\mathrm{M}_{\theta \theta}, \mathrm{f}_{3}=\mathrm{M}_{\varphi \varphi}, \mathrm{f}_{4}=\mathrm{M}_{\mathrm{r} \theta}=\mathrm{M}_{\theta \mathrm{r}}, \mathrm{f}_{5}=\mathrm{M}_{\mathrm{r} \varphi}=\mathrm{M}_{\varphi \mathrm{r}}, \mathrm{f}_{6}=\mathrm{M}_{\theta \varphi}=\mathrm{M}_{\varphi \theta} \text {. }
$$

Moment tensor-moment tensor ini menggambarkan kekuatan dari kopel gaya dari gempa.

Konsep moment tensor dapat memberi deskripsi yang lengkap tentang gaya dari sumber titik seismik. Pada umumnya moment tensor $\left[\mathrm{M}_{\mathrm{ij}}\right]$ memiliki 6 komponen moment tensor dasar independen. Jika $\mathrm{G}_{\mathrm{ki}}\left(\mathrm{x}, \mathrm{x}_{\mathrm{s}}, \mathrm{t}\right)$ adalah fungsi Green yang juga melambangkan seismogram sintetik pada stasiun ke-k dan tensor dasar ke- $\mathrm{i} ; \mathbf{M}_{\mathrm{i}}$. Seismogram yang teramati dilambangkan $U_{k}(x, t)$, maka estimasi dari koefisien $a_{i}$ untuk $\mathrm{M}_{\mathrm{i}}$ dapat dicari:

$$
\begin{aligned}
& \Delta=\sum_{k=1}^{N r} \int\left[U_{k}(x, t)-\sum_{k=1}^{6} a_{i} G\left(x, x_{s}, t\right)\right]^{2} d t \\
& =R_{x}-2 \sum_{i=1}^{6} a_{i} G_{i}+\sum_{m=1}^{6} \sum_{n=1}^{6} R_{n m} a_{n} a_{m} \\
& =\text { minimum }
\end{aligned}
$$

dimana $\mathrm{Nr}$ adalah jumlah stasiun yang digunakan.

$$
\begin{aligned}
& R_{x}=\sum_{k} \int\left[U_{k}(x, t)\right]^{2} d t \\
& R_{n m}(x)=\sum_{k} \int\left[G_{k i}\left(x, x_{s}, t\right) G_{k m}\left(x, x_{s}, t\right)\right] d t \\
& G_{i}\left(x, x_{s}\right)=\sum_{k} \int\left[G_{k i}\left(x, x_{s}, t\right) U_{k}(t)\right] d t \ldots .
\end{aligned}
$$

Kesalahan minimum dicari dengan cara menghitung derivatif pertama dari fungsi $\Delta$ terhadap parameter sebagai nol.

$$
\frac{\partial \Delta}{\partial a_{n}}=0 ; \text { untuk } \mathrm{k}=1 \text { sampai dengan } 6
$$

Dicari persamaan sbb:

$$
\sum_{m=1}^{6} R_{n m} a_{m}=G_{i}, \text { dimana } \mathrm{I}=1 \mathrm{~s} / \mathrm{d} 6 .
$$

Invers dari matrik $\left[\mathrm{R}_{\mathrm{nm}}\right]$ adalah $\left[\mathrm{R}^{\mathrm{I}}{ }_{\mathrm{nm}}\right]$, sehingga

$$
\sum_{l} R_{n l} R_{\mathrm{ln}}^{I}=\delta_{n m} \text {, dimana } \mathrm{n}, \mathrm{m}=1 \mathrm{~s} / \mathrm{d} 6 \text { dan } \delta_{\mathrm{nm}} \text { adalah delta Kronecker. }
$$

Maka diperoleh solusi:

$$
a_{i}=a_{i}^{0}=\sum_{m} R_{n m}^{l} G_{m}
$$

Sehingga diperoleh kesalahan residu:

$$
\Delta=R_{x}-\sum_{i} G_{i} a_{i}^{0}
$$

Pada tingkatan ini $a_{i}^{0}$ dan juga $\Delta$ merupakan fungsi dari parameter $\mathrm{x}$ dan $\mathrm{x}_{\mathrm{s}}$. Nilai $\mathrm{x}$ dan $\mathrm{x}_{\mathrm{S}}$ optimum ditentukan dari $\Delta$ minimum atau 


$$
\psi_{M}\left(x, x_{s}\right)=\frac{\sum_{i} G_{i} a_{i}^{0}}{R_{x}}=\frac{\sum_{i} \sum_{m} R_{i m}^{I} G_{m} G_{i}}{R_{x}}
$$

$$
=\text { minimum }
$$

$\psi_{\mathrm{M}}$ adalah korelasi antara bentuk gelombang sintetik dan hasil observasi. Faktor normalisasi $\mathrm{R}_{\mathrm{x}}$ dimunculkan sedemikian sehingga $\psi_{\mathrm{M}}=1$, pada saat bentuk gelombang sintetik dan hasil observasi identik. Begitu nilai $\mathrm{x}, \mathrm{x}_{\mathrm{s}}$ telah ditentukan, maka nilai dari $\left\{a_{i}^{0}\right\}$ diberikan oleh persamaan. Dengan menggunakan koefisien $\left\{a_{n}\right\}$, diperoleh hasil moment tensor sumber gempa sebagai berikut:

$$
\left[\mathrm{M}_{\mathrm{ij}}\right]=\left[\begin{array}{ccc}
a_{2}-a_{5}+a_{6} & a_{1} & a_{4} \\
a_{1} & -a_{2}+a_{6} & a_{3} \\
a_{4} & a_{3} & a_{5}+a_{6}
\end{array}\right]
$$

Atau ditulis dalam bentuk lain, yaitu:

$$
\mathrm{M}_{\mathrm{ij}}=\left[\begin{array}{ccc}
M_{11} & M_{12} & M_{13} \\
M_{21} & M_{22} & M_{23} \\
M_{31} & M_{32} & M_{33}
\end{array}\right]\left[\begin{array}{ccc}
M_{\mathrm{XX}} & M_{X Y} & M_{X Z} \\
M_{X Y} & M_{Y Y} & M_{Y Z} \\
M_{X Z} & M_{Y Z} & M_{Z Z}
\end{array}\right]
$$

Komponen $\mathrm{M}_{\mathrm{ij}}$ dalam kordinat bola menjadi berikut:

$$
\left[\begin{array}{ll}
M_{r r} & =M_{Z Z} \\
M_{\Theta \Theta} & =M_{X X} \\
M_{\Phi \Phi} & =M_{Y Y} \\
M_{r \Theta} & =M_{Z X} \\
M_{r \Phi} & =-M_{Z Y} \\
M_{\Theta \Phi} & =-M_{X Y}
\end{array}\right]
$$

Kesembilan komponen moment tensor tersebut dinyatakan dalam gambar sebagai berikut: 

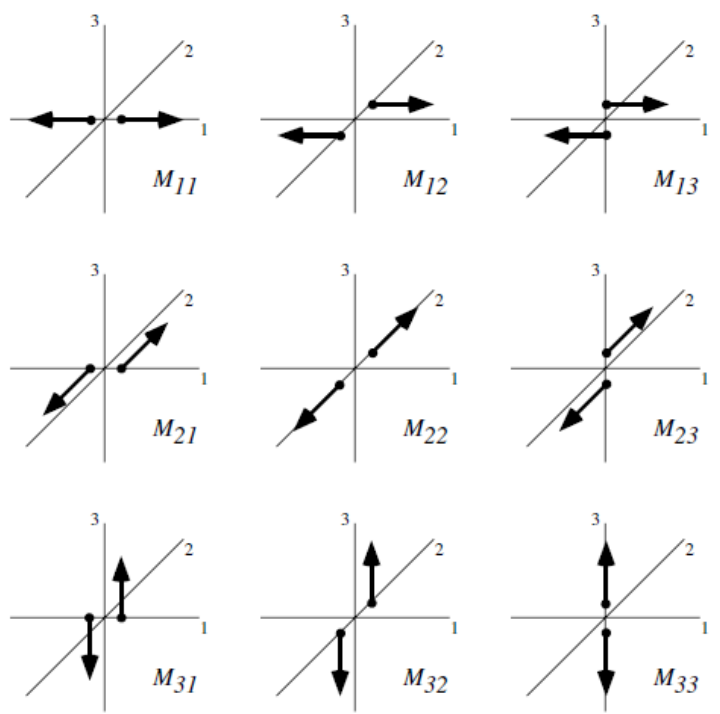

Gambar 2.1. Pasangan Gaya dari Komponen Moment tensor (Shearer, 2009)

Gaya yang bergerak ke arah i terhadap j disimbolkan dalam $\mathrm{M}_{\mathrm{ij}}$ yang merupakan komponen moment tensor. Sifat moment tesor ini simetris, karena $\mathbf{M}_{\mathrm{ij}}$ sama dengan $\mathbf{M}_{\mathrm{ji}}$. Nilai komponen $\mathrm{M}_{\mathrm{ij}}$ tersebut dapat digunakan untuk mengetahui parameter strike $(\varphi)$, dip $(\delta)$ dan rake $(\lambda)$ penyebab gempa bumi. Karena $\mathrm{M}_{\mathrm{ji}}=\mathrm{M}_{\mathrm{ij}}$, maka dari 9 moment tensor hanya tinggal 6 moment tensor independen. Hubungan moment tensor dengan strike $(\varphi)$, dip $(\delta)$ dan rake $(\lambda)$ dinyatakan dalam persamaan berikut:

$$
\begin{aligned}
& M_{11}=M_{x x}=-M_{0}(\sin \delta \cos \lambda \sin 2 \phi+\sin 2 \delta \cos \lambda \sin 2 \phi) \\
& M_{12}=M_{x y}=M_{0}(\sin \delta \cos \lambda \cos 2 \phi+0.5 \sin 2 \delta \cos \lambda \sin 2 \phi)=M_{21}=M_{y x} \\
& M_{13}=M_{x z}=-M_{0}(\cos \delta \cos \lambda \cos \phi+\cos 2 \delta \sin \lambda \sin \phi)=M_{31}=M_{z x} \\
& M_{22}=M_{y y}=M_{0}(\sin \delta \cos \lambda \sin 2 \phi-\sin 2 \delta \sin \lambda \cos 2 \phi) \\
& M_{23}=M_{y z}=-M_{0}(\cos \delta \cos \lambda \sin \phi-\cos 2 \delta \sin \lambda \cos \phi)=M_{32}=M_{x y} \\
& M_{33}=M_{z z}=-\left(M_{11}+M_{22}\right)=M_{0}(\sin 2 \delta \sin \lambda)
\end{aligned}
$$

Selanjutnya, moment tensor ini dapat digunakan untuk mengukur kekuatan gempa bumi dengan menggunakan parameter momen seismik $\left(M_{0}\right)$.

$$
M_{0}=\frac{1}{\sqrt{2}}\left[\sum_{i j} M_{i j}^{2}\right]^{1 / 2}
$$

Parameter sumber gempa bumi ini dipergunakan untuk zonasi mikro dan perlakuan resiko seismik. Focal sphere juga digunakan untuk menampilkan mekanism fokus, dimana belahan bumi rendah diplot dan kuadran kompresi dibuat berbayang untuk menghasilkan gambar "beach ball".

Selanjutnya variance reduction $\left(V_{r}\right)$ dan correlation $(C)$ dihitung dengan persamaan berikut: 


$$
\begin{aligned}
& V_{r}=1-\left[\frac{|d-s|^{2}}{|d|^{2}}\right] \\
& C=\sqrt{V_{r}}
\end{aligned}
$$

dimana:

$d=$ data observasi

$s=$ data sintetik

\section{Struktur Geologi Sesar}

Kekar atau rekahan yang tergeserkan membentuk sesar/patahan, sehingga terjadi perpindahan antar bagian-bagian yang saling berhadapan dengan arah yang sejajar bidang patahan. Zona-zona di sekitar pergeseran (zona sesar) merupakan zona lemah, zona lemah ini merupakan kawasan rawan bencana geologi, apalagi jika sesar yang terbentuk masih merupakan sesar aktif atau berada pada zona tektonik aktif (misal zona subduksi) seperti sesar-sesar di daerah Papua (Zona Sesar Hannekam, Sesar Zaagkam, Zona Sesar Wanagon, Sesar Meren Valley) yang dapat menimbulkan bencana gempa bumi (Scholz, 1990).
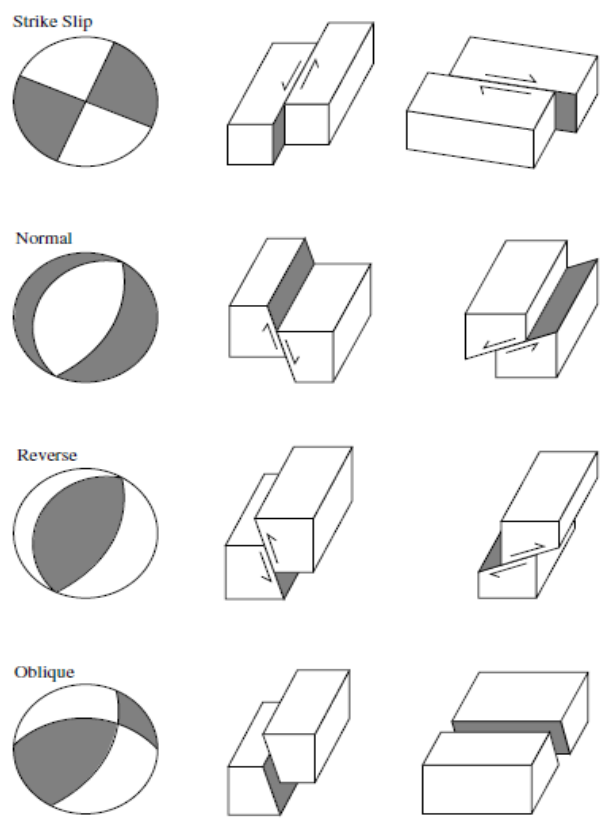

Gambar 2.2. Hubungan Focal Spheres dan Fault Geometries (Shearer, 2009)

\section{Keterangan:}

1. Sesar Strike - Slip

Terjadi pergerakan sesar secara horizontal/mendatar. Sesar strike - slip ditentukan berdasarkan pada gerakan yang menghadap bidang sesar, bila bidang didepan bergerak kekiri disebut sinistal, sedangkan bila ke kanan disebut dekstral. 


\section{Sesar Normal}

Hanging wall relatif turun terhadap foot wall, bidang sesarnya mempunyai kemiringan yang besar biasanya disebut sesar turun.

\section{Sesar reverse}

Hanging wall relatif naik terhadap foot wall, bidang sesarnya mempunyai kemiringan yang besar biasanya disebut sesar naik.

\section{Sesar Oblique}

Pergerakan sesar ini gabungan antara vertikal dan horizontal. Gaya-gaya yang bekerja menyebabkan sesar strike - slip dan sesar normal.

\section{Geologi Papua}

Papua terletak antara $1^{\circ} \mathrm{LU}-10^{\circ} \mathrm{LS}$ dan $130^{\circ}-151^{\circ} \mathrm{BT}$, wilayahnya sebelah utara berbatasan dengan Lautan Pasifik, sebelah timur berbatasan Papua Nugini, di sebelah selatan dengan Laut Arafuru, dan di sebelah barat berbatasan dengan Propinsi Maluku, mempunyai panjang $2400 \mathrm{~km}$ dan lebar $660 \mathrm{~km}$.

Papua adalah salah satu pulau terbesar di Indonesia yang memiliki kondisi geologi yang sangat kompleks karena kawasan ini terbentuk dari dua interaksi lempeng yaitu Lempeng Australia dan Lempeng Pasifik sehingga menghasilkan bentukan yang khas. Secara keseluruhan unsur ini diakibatkan oleh gaya pemampatan berarah barat dayatimur laut, searah dengan tumbukan. Selain itu juga diakibatkan benturan dengan sudut miring antara lempeng Samudera Pasifik-Lempeng Caroline yang bergerak ke selatan dengan kecepatan antara $110 \mathrm{~mm}$ - $125 \mathrm{~mm} /$ tahun terhadap tepian lempeng Benua Australia. Benturan miring lempeng-lempeng tersebut menghasilkan gerak patahanpatahan. Kombinasi thrusting dan geser di seluruh pulau Papua meliputi jalur sesar naik Membramo di utara Papua, jalur anjak perdataran tinggi (the highland thrust belt) Papua Tengah, Sesar Sorong, Ransiki, Yapen, dan Zone Sesar Tarera-Aiduna yang terkonsentrasi di sekitar Papua Barat, kepala dan leher burung Papua. Dengan kata lain, Papua Nugini merupakan fitur tektonik utama yang dapat menggambarkan batas antara Lempeng Pasifik dan Lempeng Australia (Irsyam, 2010).

Ada dua bagian kerak utama yang terlibat di Papua yaitu Kerak Australia dan Kerak Pasifik. Kerak Australia adalah mantap dan menjadi dasar bagian selatan, sedangkan Kerak Pasifik merupakan alas pantai utara termasuk Teluk Cendarwasih. Daerah badan burung merupakan jalur memanjang dari timur ke barat yang telah mengalami pelipatan. Jalur ini disebut sesar naik pegunungan tengah (JSNPT). Pada masa itu proses tektonik di daerah ini mulai terpacu sehingga menghasilkan kedudukan tumbukan yang kearah barat daya yang lebih intensif. Pertumbukan di kedua kerak tersebut mengakibatkan JSNPT membengkok dan berhenti di daerah leher burung (jalur lipatan lengguru). Bagian yang sangat menonjol dari tektonik ini adalah sistem sesar mendatar (transform fault) Mengiri yaitu sesar Sorong-Yapen (Wahyuni, 2008). 


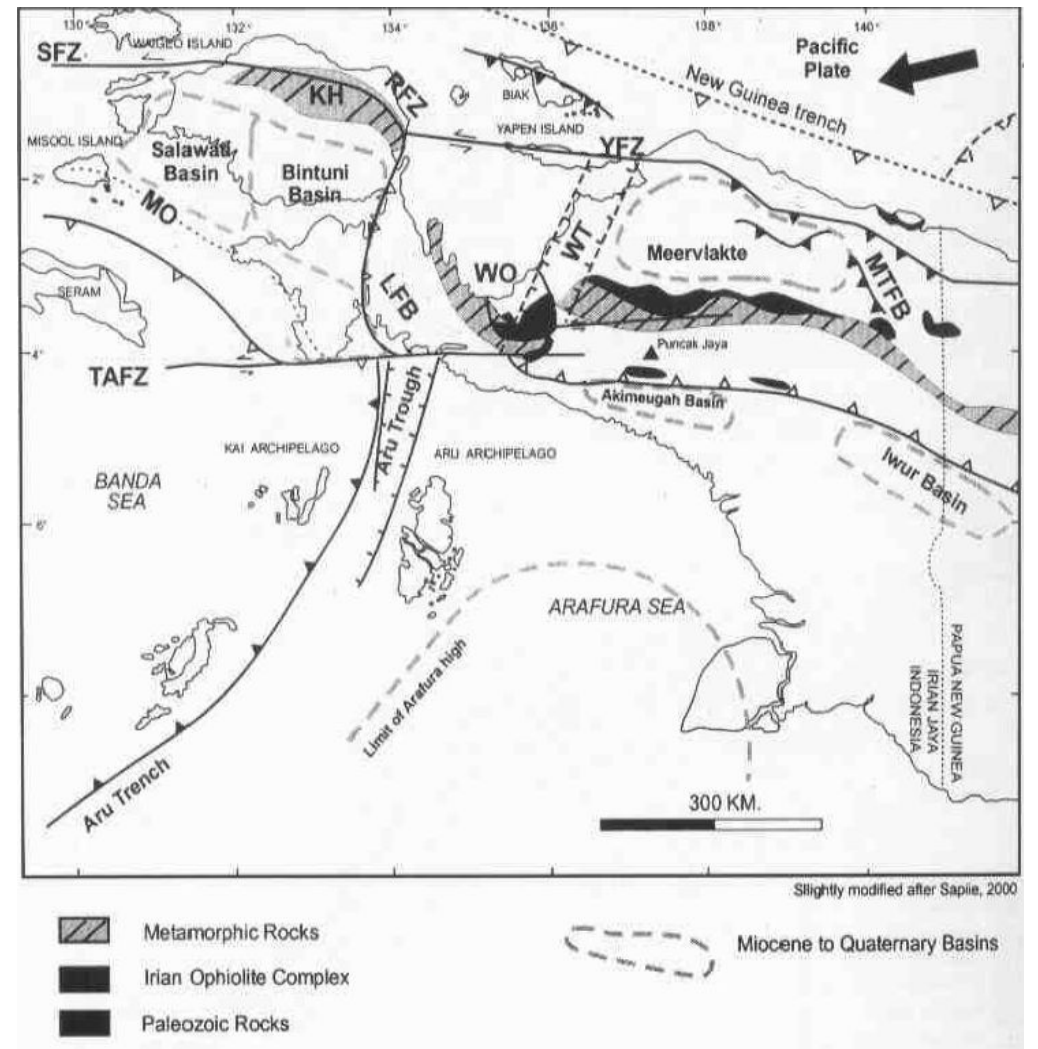

Gambar 2.3. Setting Tektonik Papua (ESDM, 2010)

\section{Keterangan:}

MTFB = Mamberamo Thrust \& Fold Belt; $\quad$ LFB = Lengguru Fault Belt

WO = Weyland Overthrust SFZ = Sorong Fault Zone

WT = Waipona Trough $\quad$ YFZ = Yapen Fault Zone

TAFZ = Tarera-Aiduna Fault Zone $\quad$ MO = Misool-Onin High.

RFZ = Ransiki Fault Zone

*Tanda panah menunjukkan gerakan relatif antara lempeng Pasifik dan Australia.

\section{METODE PENELITIAN}

\section{Inversi Waveform Tiga Komponen}

Inversi adalah menentukan suatu himpunan model parameter yang tidak diketahui $\mathbf{m}=\left[\mathbf{m}_{\mathbf{i}}\right](\mathrm{i}=1,2,3, \ldots . ., \mathrm{N})$ dari himpunan data hasil pengamatan $\mathbf{d}=\left[\mathbf{d}_{\mathbf{i}}\right](\mathrm{I}=1,2,3$, ....., M). Untuk data dengan parameter model suatu fungsi linier, persamaannya dapat dinyatakan sebagai:

$$
d=\underline{G} m
$$

Dimana $\underline{\mathbf{G}}$ adalah matriks ( $\mathrm{N}$ x $\mathrm{M}$ ) yang sering disebut sebagai matriks kernel. Sehingga dalam matriks, hubungan antara data dengan parameter model tersebut dapat dituliskan sebagai berikut: 


$$
\left[\begin{array}{l}
d_{1} \\
d_{2} \\
\ldots \\
d_{N}
\end{array}\right]=\left[\begin{array}{cccc}
G_{11} & G_{21} & \ldots & G_{1 M} \\
G_{21} & G_{22} & \ldots & G_{2 M} \\
\ldots & \ldots & \ldots & \ldots \\
G_{N 1} & G_{N 2} & \ldots & G_{N M}
\end{array}\right]\left[\begin{array}{l}
m_{1} \\
m_{2} \\
\ldots \\
m_{N}
\end{array}\right]
$$

Selain itu dapat pula dinyatakan dalam bentuk komponen-komponennya menggunakan notasi penjumlahan berikut:

$$
d_{i}=\sum_{j=1}^{M} G_{i j} m_{j} ; \quad i=1,2, \ldots \ldots, N .
$$

Selanjutnya solusi inversi linier dari parameter model m dapat dituliskan dalam persamaan berikut:

$$
m=\left\lfloor\underline{G}^{T} \underline{G}\right\rfloor^{-1} \underline{G}^{T} d
$$

dimana $\underline{G^{T}} \underline{G}$ adalah matriks bujur sangkar berukuran (N x M) sesuai dengan jumlah parameter model yang dicari.

Eksistensi solusi inversi linier di atas ditentukan oleh sejauhmana data dapat mendefinisikan atau mengkarakterisasi parameter model serta perbandingan jumlah data terhadap jumlah parameter model. Umumnya diasumsikan bahwa jumlah data selalu jauh lebih besar daripada jumlah parameter model $(\mathrm{N}>\mathrm{M})$ sehingga permasalahannya bersifat over-determined.

Pada analisis seismogram tiga komponen ini, jenis inversi yang digunakan adalah inversi linier. Permasalahannya bersifat over-determined, dimana jumlah data jauh lebih besar daripada jumlah parameter model $(\mathrm{N}>\mathrm{M})$. Sehingga solusi matematis dari parameter model $\mathbf{m}$ yang digunakan adalah:

$$
m=\left\lfloor\underline{G}^{T} \underline{G}\right\rfloor^{-1} \underline{G}^{T} d
$$

Pada analisis ini, digunakan waveform lokal tiga komponen. Parameter-parameter sumber gempa bumi diestimasi dengan menggunakan model inversi untuk mencapai fitting waveform 3 komponen dengan baik. Proses inversi yang baik didasarkan hasil pencocokkan data observasi dan data sintetik yang dihasilkan dalam proses inversi. Hasil yang baik terjadi jika data observasi dan data sintetik saling tumpang tindih.

Seismogram teleseismik komponen direkam oleh network IA, selanjutnya diinversi dengan menggunakan fungsi Green yang dihitung dengan metode diskritisasi bilangan gelombang yang dilakukan secara iterasi (Bouchon, 1981). Untuk menghitung fungsi Green digunakan model kecepatan $1 \mathrm{D}$ dan hiposenter pada beberapa event dari 
IA. Model kecepatan yang digunakan pada penelitian ini ialah berdasarkan Haslinger (1999) yang telah dimodifikasi sebagaimana gambar berikut.

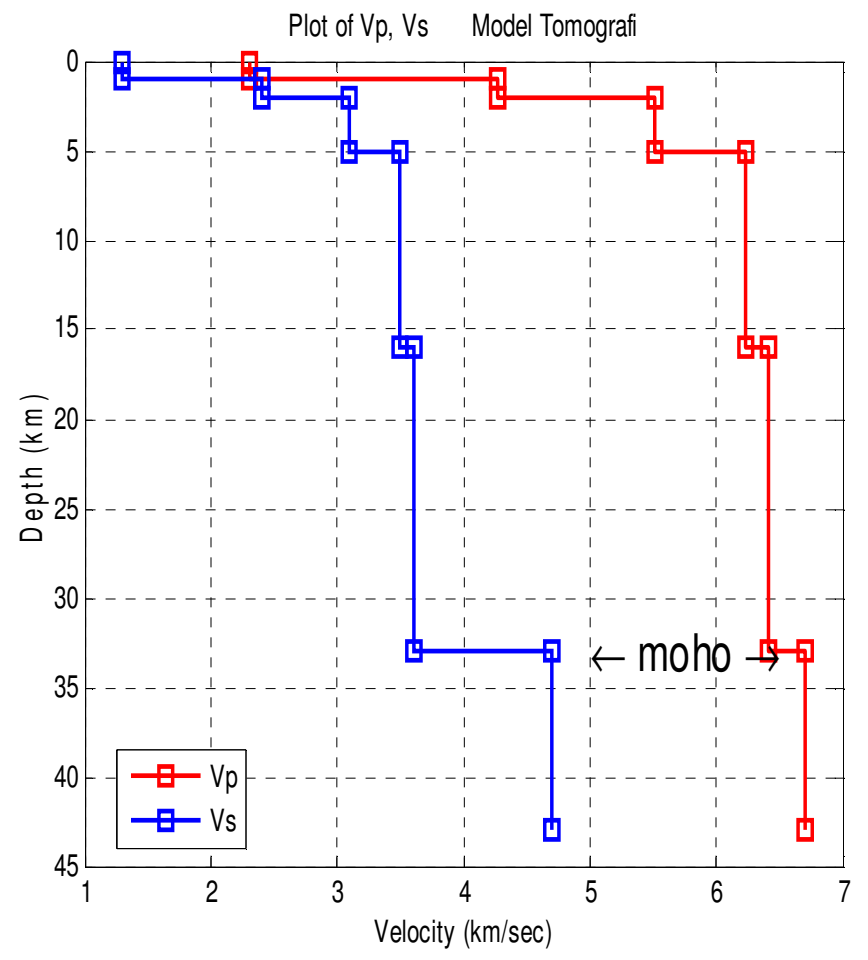

Gambar 3.1. Model Kecepatan Inversi Moment tensor (ISOLA, 2010)

Selanjutnya dilakukan proses inversi data waveform tiga komponen dengan menggunakan metode iterasi dekonvolusi (Zahradnik, 2006). Metode ini diimplementasikan dalam software ISOLA yang dikembangkan untuk mendapatkan parameter-parameter sumber gempa bumi (Sokos, 2008). Parameter-parameter gempa ini tergambarkan dengan menggunakan Centroid Moment Tensor (CMT) atau beach ball, parameter sesar penyebab gempa dan kedalaman Gempa bumi. Selanjutnya, hasil parameter-patameter tersebut digunakan untuk mengetahui bentuk patahan yang sebenarnya (fault-plane) dengan menggunakan metode H-C (Zahradnik, 2008). Konstruksi software ISOLA yang digunakan seperti pada gambar berikut: 


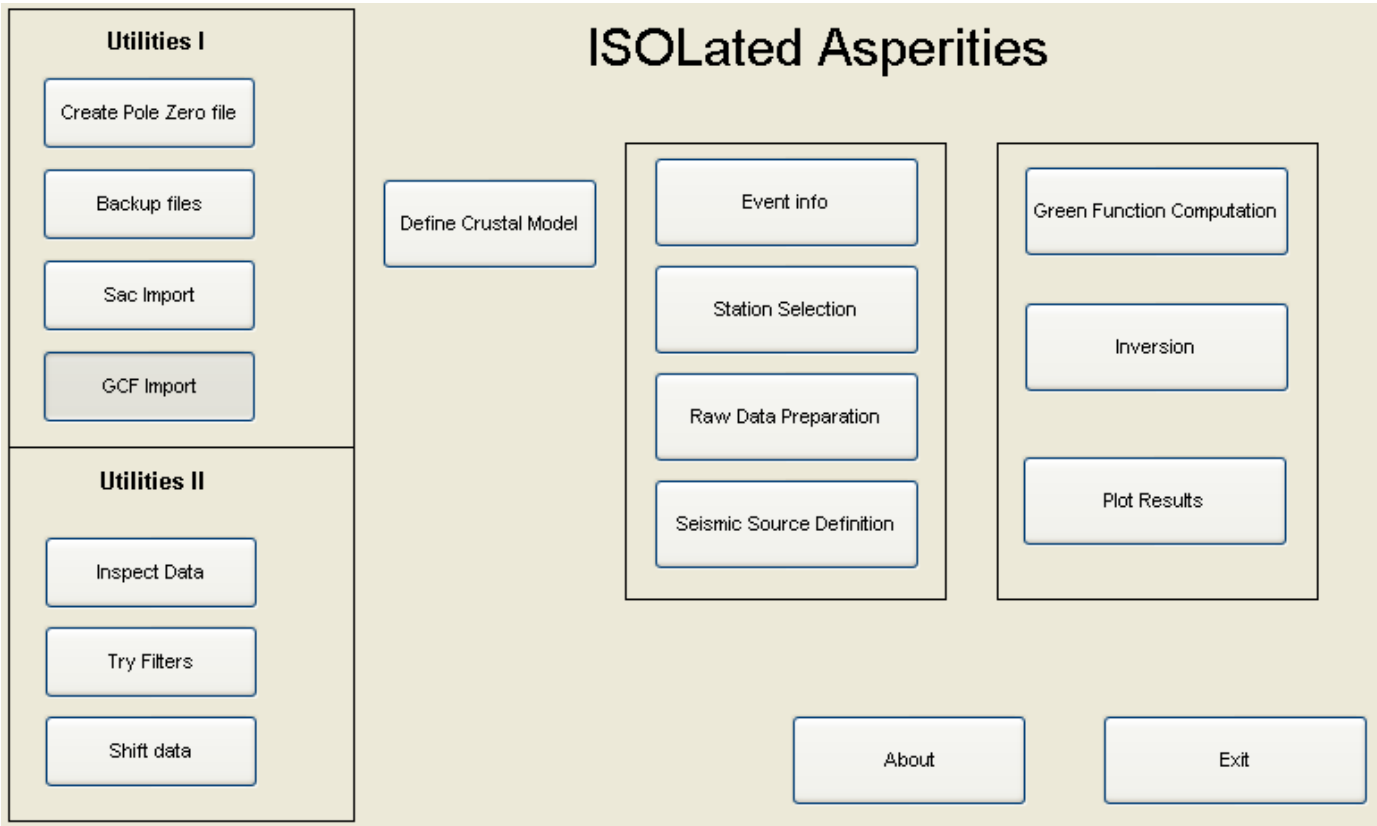

Gambar 3.2. Solusi moment tensor dengan software ISOLA

\section{ANALISA DATA}

Data yang digunakan dalam penelitian ini adalah data seismik lokal yang diunduh dari data gempa IA, yaitu gempa bumi yang terjadi di Manokwari Papua pada tanggal 3 Januari 2009 pukul 19:43:55 GMT dan mempunyai hiposenter pada latitude -0.70541, lontitude 125.8455 pada kedalaman $25 \mathrm{~km}$ (http://geofon.gfz-potsdam.de/geofon/).

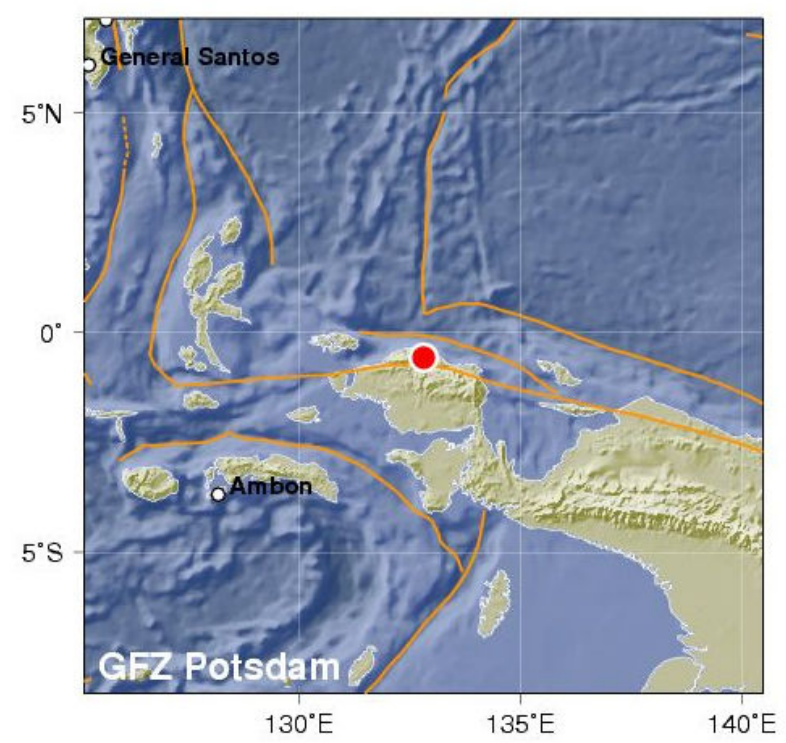

Gambar 3.1. Lokasi Gempa Bumi 3 Januari 2009 (Geofon, 2010) 
Stasiun yang dipilih adalah 3 stasiun terdekat dengan posisi sumber gempa, yaitu BAK, LBM, dan JAY. Pada analisis data ini, digunakan waveform tiga komponen (BHN, BHE dan BHZ). Parameter-parameter sumber gempa bumi ini diestimasi dengan menggunakan model inversi untuk mencapai fitting waveform tiga komponen yang baik. Proses inversi yang baik didasarkan hasil pencocokkan data observasi dan data sintetik hasil inversi, dimana hasil yang baik terjadi saat data observasi dan data sintetik saling tumpang tindih. Perbandingan hasil data observasi dan data sintetik seperti terlihat pada gambar berikut:

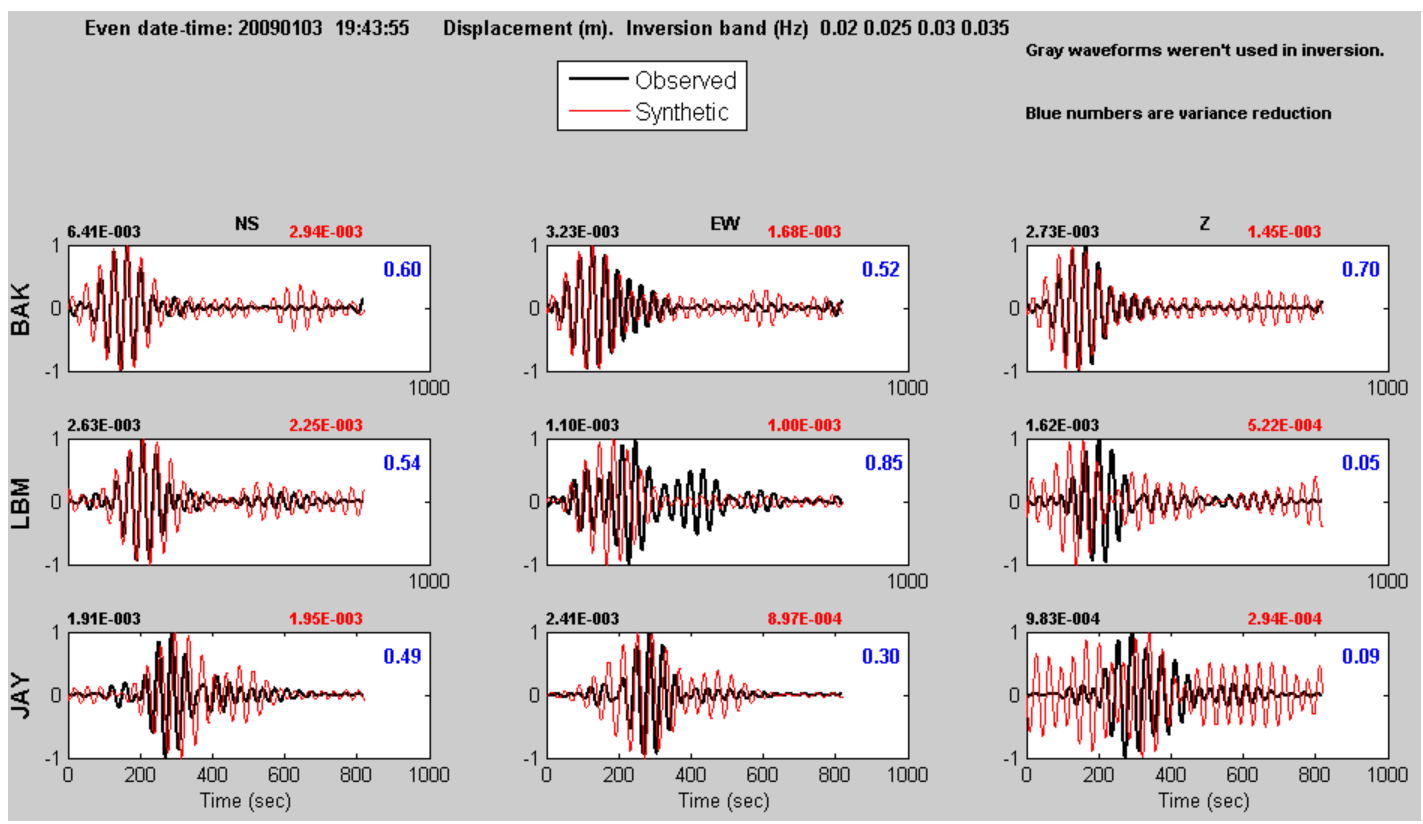

Gambar 3.2. Waveform Observasi dan Sintetik

Selanjutnya, interpretasi dilakukan pada centroid moment tensor (CMT). Menurut Kayal (2008), CMT merupakan penggambaran model sesar penyebab gempa bumi. CMT yang digambarkan dengan beach ball mempunyai arti fisis yakni, bagian yang cerah merupakan asal gaya yang menekan ke arah bagian yang gelap (Shearer, 2009).

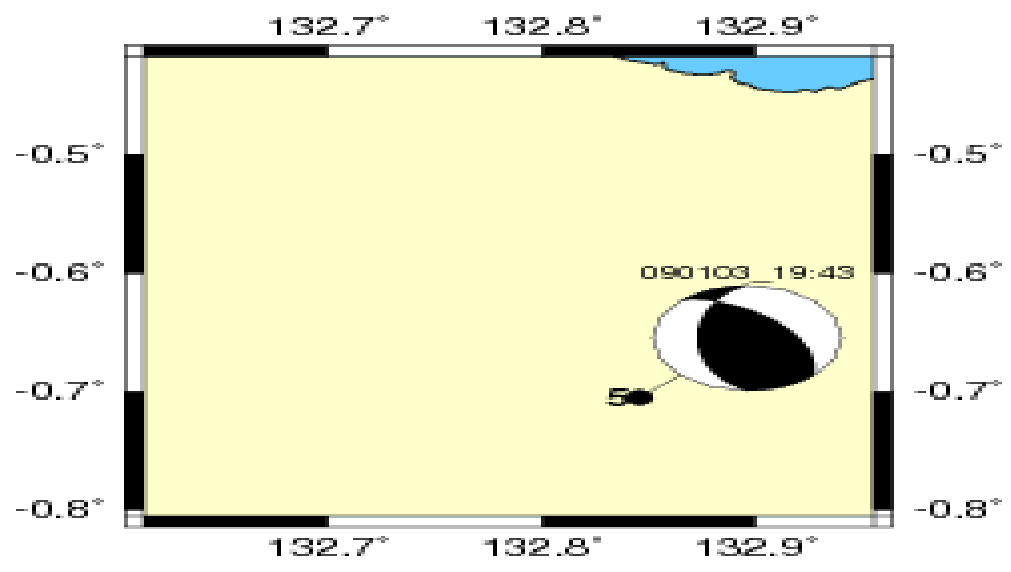

Gambar 3.3. Moment Tensor Gempa Bumi 3 Januari 2009 
Hasil CMT pengolahan data gempa bumi di Manokwari Papua pada tanggal 3 Januari 2009 tersebut menunjukkan bahwa penyebab gempa bumi ini berupa sesar strike-slip oblique.

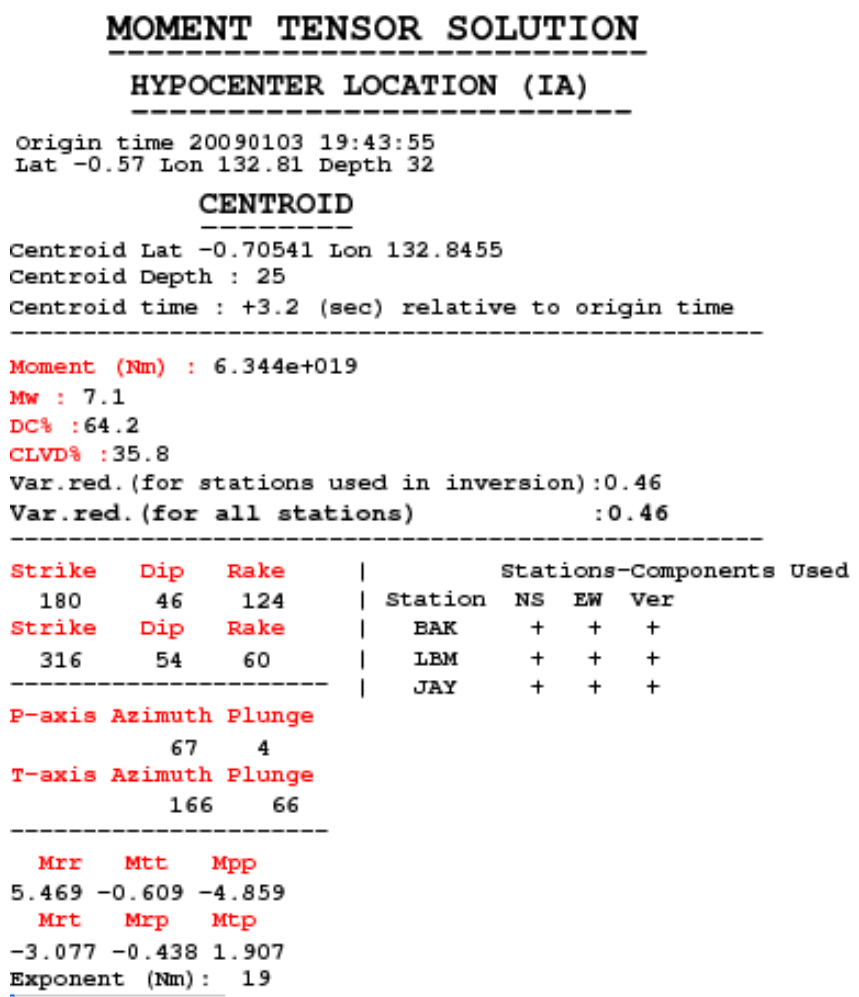

Gambar 3.4. Parameter Sumber Gempa

Hasil inversi berupa parameter gempa di atas didapatkan bahwa magnitude gempa sebesar 7.1 Mw dan varian reduksi sebesar 0.46 dengan DC 64.2\%, dan CLVD 35.8\%. Hasil data parameter sumber gempa tersebut jika dibandingkan dengan data BMG dan USGS yang didapatkan dari Tim Tanggap Darurat Pusat Vulkanologi dan Mitigasi Bencana Geologi (TTD-PVMBG), Badan Geologi, DESDM akan terlihat dalam tabel berikut:

Tabel 3.1. Perbandingan Parameter Sumber Gempa BMG, USGS, dan Penulis

\begin{tabular}{|l|l|l|l|l|l|}
\hline Agency & Lattitude & Longitude & Event & $\begin{array}{c}\text { Kedalaman } \\
(\mathbf{k m})\end{array}$ & Magnitude \\
\hline BMG & -0.42 & 132.93 & $02: 43: 51 \mathrm{WIB}$ & 10 & $7.2 \mathrm{SR}$ \\
\hline USGS & -0.510 & 132.78 & $02: 43: 55 \mathrm{WIB}$ & 35 & $7.6 \mathrm{Mw}$ \\
\hline Penulis & -0.70541 & 132.8455 & $19: 43: 55 \mathrm{GMT}$ & 25 & $7.1 \mathrm{Mw}$ \\
\hline
\end{tabular}

Selanjutnya parameter strike dan dip digunakan untuk penggambarkan fault-plane penyebab gempa bumi. Penggambaran dilakukan dengan menggunakan software hc- 
plot yang didasarkan pada metode H-C (Zadradnik et al., 2008). Input yang dimasukkan dalam software hc-plot ini sebagai berikut:

$\begin{array}{llll}\text { Hiposenter } & \text { lat }=-0.57 & \text {; lon }=132.81 & \text {; depth }=32 \\ \text { Centroid } & \text { : lat }=-0.70541 & ; \text { lon }=132.845 & \text {; depth }=25 \\ \text { Plane } 1 & \text { : strike } \quad=180 & ; \text { dip }=46 & \\ \text { Plane 2 } & \text { : strike } \quad=316 & ; \text { dip }=54 & \end{array}$

Selanjutnya dihasilkan output jarak centroid hiposenter $=16.9813$, jarak minimum dari bidang $1=3.0568$, dan jarak minimum dari bidang $2=2.5434$, sehingga hasil penggambaran fault-plane gempa Manokwari Papua tanggal 3 Januari 2009 seperti pada gambar 3.5, yaitu patahan penyebab gempa bumi berwarna merah. Artinya, patahan ini berarah barat laut - tenggara.

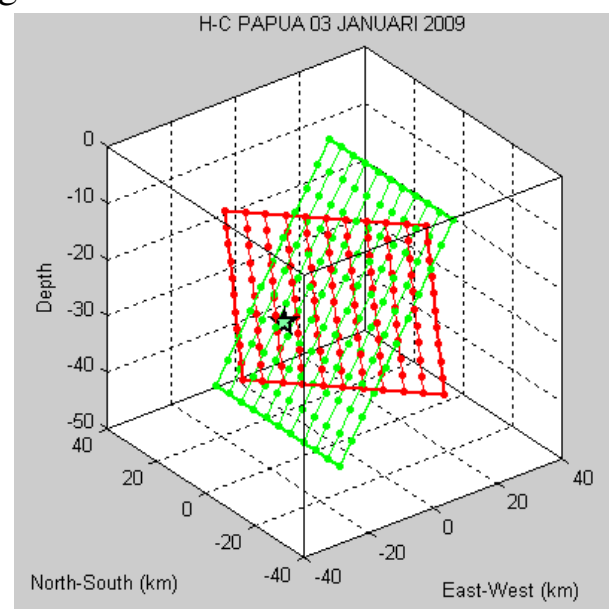

Gambar 3.5. Fault-Plane berdasarkan CMT

Lokasi pusat gempa bumi pada tanggal 3 Januari 2009 dengan magnitude $7.1 \mathrm{Mw}$ yang episentrumnya berada pada lattitude -0.70541 , longitude 125.8455 dan kedalaman $25 \mathrm{~km}$ terletak di barat laut Manokwari. Manokwari termasuk dalam propinsi Papua Barat. Propinsi ini memiliki intensitas kegempaan yang tinggi, terutama dengan kedalaman dangkal dari sistem sesar aktif yang berpotensi merusak. Hal ini disebabkan terletak dekat jalur penunjaman Lempeng Pasifik dan Kerak Australia di bagian utara yang merupakan "sumber gempa bumi". Akibat evolusi tektonik terbentuk beberapa sesar aktif, yaitu : Sesar Sorong, Sesar Ransiki, Sesar Tarera Aiduna, dan Sesar naik di Pegunungan Jayawijaya. Selain itu, kondisi daerah bencana gempa bumi pada umumnya disusun oleh batuan metamorf berumur Pra Tersier, batuan sedimen berumur Tersier dan batuan sediment berumur Kuarter. Batuan berumur Pra Tersier dan Tersier yang telah mengalami pelapukan dan batuan berumur Kuarter pada umumnya bersifat lepas, lunak, belum padu (unconsolidated) dan memperkuat efek getaran gempa bumi sehingga rentan terhadap goncangan gempa bumi (PVMBG, 2009). Lebih lanjut penyebab gempa bumi 3 Januari 2009 tersebut terjadi akibat aktivitas sistem Sesar Aktif Sorong yang terdapat di bagian utara Manokwari. Sesar Sorong membentang mulai dari Manokwari, Kepala Burung, Provinsi Maluku hingga lengan timur Sulawesi. 


\section{KESIMPULAN}

Analisa data gempa melalui inversi waveform 3 komponen dilakukan dengan menggunakan software ISOLA yang bertujuan untuk mengestimasi CMT, Fault Plane dan paramater sumber gempa. Analisa dilakukan pada data gempa yang terjadi di Papua dengan magnitude 7.1 Mw yang episentrumnya berada pada lattitude -0.70541, longitude 125.8455 dan kedalaman $25 \mathrm{~km}$ terletak di barat laut Manokwari dari data IA. Hasil analisis ini diketahui bahwa sesar penyebab gempa bumi termasuk dalam sesar strike-slip oblique yang bergerak berarah barat laut - tenggara.

\section{DAFTAR PUSTAKA}

Aki, K. and Richards, P.G., 1980, Quantitative Seismology: Theory and Methods,W.H. Freeman, San Francisco, CA.

Bouchon, M., 1981, A Simple Method to Calculate Green's Functions for Elastic Layered Media, Bulletin of the Seismological Society of America, 71, 959-971.

Irsyam, M., dkk, 2010, Hasil Study Tim Revisi Peta Gempa Indonesia, Bandung.

Lasitha, S., Radhakrishna, M., ande Sanu, T.D., Seismically Active Deformation in the Sumatra-Java Trench-arc Region: Geodynamic Implications, Current Science, Vol. 90 No. 5, 10 March 2006.

Lay, T. and Wallace, Terry C., 1995, Modern Global Seismology, Academic Press, New York, USA, $521 \mathrm{p}$.

McCafferey, R., 2009, The Tectonic Framework of the Sumatran Subduction Zone, Annu. Rev. Earth Planet. Sci. Vol 37, pp 345-366.

Kayal, J.R., 2008, Microearthquake Seismology and Seismotectonics of South Asia, Springer. India.

Kikuchi, M. and H. Kanamori, 1991, Inversion Of Complex Body Waves - III, Bulletin of the Seismological Society of America, 81, 2335-2350.

Pusat Vulkanologi dan Mitigasi Bencana Geologi, 2009, Laporan Gempa Bumi Manokwari.

Santosa, B.J., 2006, Seismogram Analyzing of Earthquake b122696c, Рapua at Surrounding Observasional Stasions; Jurusan Fisika, FMIPA, ITS,

Shearer, P.M., 2009, Introduction To Seismology Second Edition, Cambridge University Press

Sieh K, Natawidjaja D., 2000, Neotectonics of the Sumatran fault, Indonesia, J. Geophys. Res. 105:28295-256. 
Sokos, and Zahradník, J., 2008, ISOLA a Fortran Code and a Matlab GUI to Perform Multiple-Point Source Inversion of Seismic Data. Computers \& Geosciences 34, 967-977

Wahyuni, L.I., 2008, Geology Irian Jaya, Jurusan Geografi, Universitas Negeri Malang.

Zahradnik, J., Gallovic F., E. Sokos, A. Serpetsidaki and G-A. Tselentis., 2008, Quick Fault-Plane Identification by a Geometrical Method: Application to the Mw 6.2 Leonidio Earthquake, 6 January 2008, Greece. Seismological Research Letters Volume 79, Number 5, September/October 2008, 653-662.

Zahradnik J., Serpetsidaki A., Sokos, E. and Tselentis G.A, 2006, Iterative deconvolution of regional waveforms and a double-event interpretation of the lefkada earthquake, Greece (http://seismo.geology.upatras.gr/isola/). 